\title{
A possible role for Epstein-Barr virus in the pathogenesis of pleural effusion
}

\author{
S.F.T. Thijsen*, R. Luderer", J.M.H. van Gorp", S.J.G. Oudejans" ${ }^{\#}$ and A.W.J. Bossink
}

ABSTRACT: A high percentage of pleural effusions remain unexplained despite an intensive diagnostic workup. Epstein-Barr virus (EBV) infections occur worldwide and affect the majority of the population. The present study investigated the prevalence and clinical relevance of EBV in pleural effusions.

A prospective study was performed in which 60 consecutive patients with pleural effusion were enrolled. Real-time quantitative EBV-PCR was performed on pleural fluid and serum. Pleural fluid was further evaluated using standard biochemical, cytological and microbiological procedures. Demographic data, medical history and medication were recorded.

A total of $24(40 \%)$, from 60 pleural fluids tested, were positive in the EBV-PCR. Median EBVDNA levels for positive samples was 454 genome equivalents (geq) $\mathrm{mL}^{-1}$ (range $36-163,446$ geq $\left.\cdot \mathrm{mL}^{-1}\right)$. A total of $20(59 \%)$ out of 34 unexplained pleural effusions were EBV-PCR positive. Serological analysis of all patients with a positive PCR revealed a previous infection. Patients with a positive EBV-PCR on pleural fluid were more likely to have a positive EBV-PCR on serum than patients with a negative PCR on pleural fluid.

Epstein-Barr virus reactivation in pleural fluid is a frequent event and the absence of an alternative diagnosis to explain the nature of the effusion in the majority of cases suggests an aetiological role for Epstein-Barr virus in the development of pleural effusion.

\section{KEYWORDS: Epstein-Barr virus, pleural effusion}

pstein-Barr virus (EBV) infections occur commonly and worldwide $>90 \%$ of the adult population is infected [1]. In childhood, primary infections are mostly subclinical, during adolescence the infection may present as infectious mononucleosis. EBV infections begin with a lytic phase followed by a latent phase [2]. During the lytic phase, active reproduction of the virus takes place and new cells become infected. EBV uses latent infection as an immune evasion strategy to prevent cytotoxic T-cell elimination of infected cells. During this latent phase EBV alters its gene expression to a state in which only few viral proteins are produced. Systemic reactivation of viral infection is possible whenever control of T-cell lymphocytes is inadequate, for example in patients who are given bone marrow transplantation [3], patients with solid transplants [4], patients infected with HIV [5] or patients with chronic active EBV infections [6]. Local reactivation in the oropharynx, with shedding of EBV, can be detected in $\sim 70 \%$ of healthy individuals infected with EBV, this is probably due to insufficient T-cell control in the saliva [7].

For editorial comments see page 566.
Pleural effusion is a common finding, which often remains unexplained [8]. The prevalence of EBV in pleural effusions is not known, although pleural effusion has been described in patients with primary EBV infection [9-11]. These findings prompted the initiation of a prospective trial to determine the prevalence of EBV in pleural fluid and its clinical relevance.

\section{MATERIALS AND METHODS \\ Patients}

All patients with suspected pleural effusion, based on radiological examination, were eligible for the study. No exclusion criteria were defined. A total of 60 consecutive patients, from whom pleural fluid was obtained, were included. All patients gave informed consent. Routine cytological, biochemical, and microbiological tests were performed on the pleural effusion. Demographic data, medical history and medication were recorded. Effusions were classified as being transudative or exudative based on the criteria defined by Heffner et al. [12].

\section{Serology}

Immunoglobulin (Ig) $\mathrm{M}$ antibodies against EBV viral capsid antigen (VCA) and IgG antibodies
AFFILIATIONS

*Dept of Microbiology,

\#Unit Molecular Diagnostics,

-Dept of Pathology and

+Dept of Pulmonology and Heart

Lung Center Utrecht,

Diakonessenhuis Utrecht, The

Netherlands.

CORRESPONDENCE

S.F.T. Thijsen

Diakonessenhuis

Dept of Microbiology

Bosboomstraat 1

3582 KE Utrecht

The Netherlands

Fax: 31302566695

E-mail: sthijsen@diakhuis.nl

Received:

November 152004

Accepted after revision:

May 222005 
against EBV VCA and EBV nuclear antigen (EBNA) were determined in serum using the Meridian bioscience ELISA (Meridian, Ohio, USA). Heterophilic antibodies were determined using the Monospot test (Meridian). Infection in the past was defined as the presence, in serum, of IgG antibodies against VCA and/or EBNA, in combination with the absence of IgM antibodies against VCA, and the absence of heterophilic antibodies. Primary infection was defined as patients with detectable IgM antibody levels against VCA and negative IgG antibodies against EBNA.

\section{DNA isolation and PCR}

Pleural fluid samples were divided into two, one-half was stored at $-80^{\circ} \mathrm{C}$ until use, while the second-half was centrifuged at $600 \times g$ for $10 \mathrm{~min}$. Both the supernatant, having been transferred to a new tube, and the pellet were stored, separately, at $-80^{\circ} \mathrm{C}$ until use. DNA was isolated using the QIAmp DNA mini-kit (Qiagen, Venlo, The Netherlands) according to the instructions of the manufacturer. A quantitative real-time EBV PCR, targeting the nonglycosylated membrane antigen BNRFp143 gene, was performed in duplicate on each sample, based on the protocol described by NIESTERS et al. [13] using the ABI Prism 7000 sequence detection system (Applied Biosystems, Foster City, CA, USA). Quantification was performed using standard curves derived from a stock of EBV (EBV B95-8; Advanced Biotechnologies Incorporated, Colombia, MD, USA) which had been quantified by electron microscopy. A mean standard curve was calculated based on the average cycle threshold $(\mathrm{Ct})$-values of 26 standard curves. As an internal control, all samples were spiked with Phocine herpes virus-1 [14]. EBV PCR results were regarded positive when both duplicate reactions generated a detectable $\mathrm{Ct}$-value. The experiment was repeated if only one of the duplicate reactions was positive. Each extraction-round and each PCRrun included negative control samples. None of these samples produced signals above the threshold value for the EBV fluorescence signal, indicating that no false-positive results were encountered.

\section{In situ hybridisation}

Pleural fluid with an EBV load of $>1,000$ genome equivalent (geq) $\cdot \mathrm{mL}^{-1}$ was subjected to in situ hybridisation (ISH). ISH was performed on five micrometer-cut sections of formalinfixed and paraffin-embedded pellet material using an EBVencoded RNA (EBER) protein nucleic acid (PNA) probe (probe $Y$ 5200; Dakocytomation, Heverlee, Belgium), which is complementary to two EBV-encoded nuclear RNAs.

\section{Statistical analysis}

Continuous data are expressed as median (range) and groups were compared using the Mann-Whitney U-test, to account for non-Gaussian distributions. Noncontinuous data were analysed using the Chi-squared test, and Fisher's exact test, whenever expected frequencies in cells were $<5$.

\section{RESULTS}

A total of 60 patients were included; patient demographics are listed in table 1. Quantitative real-time EBV-PCR of the pleural fluid was positive in $24(40 \%)$ patients, 36 samples tested negative, although the internal control of two samples (both from patients with empyema) showed some inhibition (3-4

\begin{tabular}{|c|c|c|c|}
\hline & $\begin{array}{c}\text { Positive EBV } \\
\text { PCR on PF }\end{array}$ & $\begin{array}{c}\text { Negative EBV } \\
\text { PCR on PF }\end{array}$ & p-value \\
\hline Patients $\mathbf{n}$ & 24 & 36 & \\
\hline \multicolumn{4}{|l|}{ Age yrs } \\
\hline Mean & 68 & 63 & NS \\
\hline Median (range) & 68 (39-95) & $68(5-92)$ & NS \\
\hline Follow-up mean \pm SD days & $175 \pm 90$ & $177 \pm 61$ & NS \\
\hline Sex & & & NS \\
\hline Male & 17 & 18 & \\
\hline Female & 7 & 18 & \\
\hline Fever & $4 / 17$ & $9 / 19$ & NS \\
\hline Malignancy & $12 / 12$ & $16 / 19$ & NS \\
\hline Immunesuppressive drugs & $6 / 17$ & $3 / 27$ & NS \\
\hline Smoking & $10 / 7$ & $11 / 9$ & NS \\
\hline Cough $^{\#}$ & $7 / 10$ & $4 / 24$ & NS \\
\hline Thoracic pain & $9 / 8$ & $8 / 20$ & NS \\
\hline Dyspnoea\# $^{\#}$ & $15 / 2$ & $25 / 3$ & NS \\
\hline Mortality & $9 / 15$ & $10 / 26$ & NS \\
\hline
\end{tabular}

Data presented as yes/no unless otherwise stated. EBV: Epstein Barr Virus; PF pleural fluid, NS: not significant. ${ }^{\#}$ : Fisher's exact test.

Ct-values). Median value for positive samples was 454 geq $\cdot \mathrm{mL}^{-1}$ (range $36-163,446 \mathrm{geq} \cdot \mathrm{mL}^{-1}$ ) with a mean of 11,554 geq $\cdot \mathrm{mL}^{-1}$ (table 2 ). In three pleural fluids the EBV-DNA level was $>10,000 \mathrm{geq} \cdot \mathrm{mL}^{-1}$, in six cases the EBV-DNA level was between $1,000-10,000 \mathrm{geq} \cdot \mathrm{mL}^{-1}$ and in 15 cases the EBV-DNA level was between $36-1,000 \mathrm{geq} \cdot \mathrm{mL}^{-1}$. None of the parameters listed in table 1 showed a significant difference between patients with or without EBV in their pleural fluid.

\begin{tabular}{|c|c|c|c|}
\hline \multirow[t]{2}{*}{ TABLE 2} & \multicolumn{3}{|c|}{$\begin{array}{l}\text { Epstein-Barr virus (EBV) analysis of pleural fluid } \\
\text { and serum }\end{array}$} \\
\hline & & $\begin{array}{l}\text { Positive EBV } \\
\text { PCR on PF }\end{array}$ & $\begin{array}{c}\text { Negative EBV } \\
\text { PCR on PF }\end{array}$ \\
\hline PF EBV PCF & & 24 & 36 \\
\hline \multicolumn{4}{|c|}{ PF EBV load geq $\cdot \mathrm{mL}^{-1}$} \\
\hline Mean & & 11554 & 0 \\
\hline Median & & 454 & \\
\hline Range & & $36-163446$ & \\
\hline \multicolumn{4}{|c|}{ Serum EBV PCR } \\
\hline Positive & & 6 & 0 \\
\hline Negative & & 12 & 26 \\
\hline Serum EBV & ad geq $\cdot \mathrm{mL}^{-1}$ & & 0 \\
\hline Mean & & 2209 & \\
\hline Median & & 89 & \\
\hline Range & & $52-12832$ & \\
\hline \multicolumn{4}{|c|}{ EBV serology } \\
\hline Naive & & 0 & 3 \\
\hline Acute infec & & 0 & 0 \\
\hline Past infecti & & 18 & 23 \\
\hline
\end{tabular}

PF: pleural fluid; geq: genome equivalent. 
For the first 16 patients with a positive EBV PCR of the pleural fluid, the pleural fluid was centrifuged and supernatant and pellet material were analysed separately for the presence of EBV-DNA and compared with the EBV-PCR results on the noncentrifuged pleural fluid sample. Although the distribution of EBV between supernatant and pellet was variable (fig. 1), EBV DNA was detected in the supernatant of pleural fluid in $50 \%$ of the cases. Since no clear difference was found between the supernatant and the pellet, analysis of successive patients was carried out on noncentrifuged pleural fluid. ISH for detection of EBV infection was attempted in the nine pleural fluids with an EBV-DNA level $>1,000 \mathrm{geq} \cdot \mathrm{mL}^{-1}$, only six of which were found to have sufficient cells present in the paraffin-embedded pellet-material. In these six pleural fluids, EBV could not be detected by ISH. The presence of EBV, as assessed by PCR, in pellet and supernatant was determined in four out of these six samples. All samples were EBV-PCR positive in the pellet and three of the four were positive in the supernatant.

Serological analysis of patients with a positive EBV-PCR of the pleural fluid was possible in 18 cases, from the other six patients no serum was obtained, serological results from these 18 patients indicated a previous infection (table 2). EBV was detected more often in the serum of patients with a positive EBV-PCR of the pleural fluid when compared with patients that had a negative EBV-PCR of the pleural fluid $(p=0.002)$. This finding was also seen in pleural fluids with EBV-DNA levels ranging from undetectable to $100 \mathrm{geq} \cdot \mathrm{mL}^{-1}(\mathrm{p}<0.001$; Fisher's exact test). However, in patients with a positive EBVPCR in pleural fluid, of whom serum was obtained $(n=18)$, EBV-PCR was negative in $12(67 \%)$, indicating that the absence of EBV in serum does not exclude the presence of EBV in pleural fluid. EBV was not detected in the serum of patients with a negative EBV-PCR of the pleural fluid.

Table 3 summarises radiological, biochemical and cytological data. Transudates and exudates were discriminated based on the criteria defined by HEFFNER et al. [12]. Most transudates were detected in patients with a negative EBV-PCR on

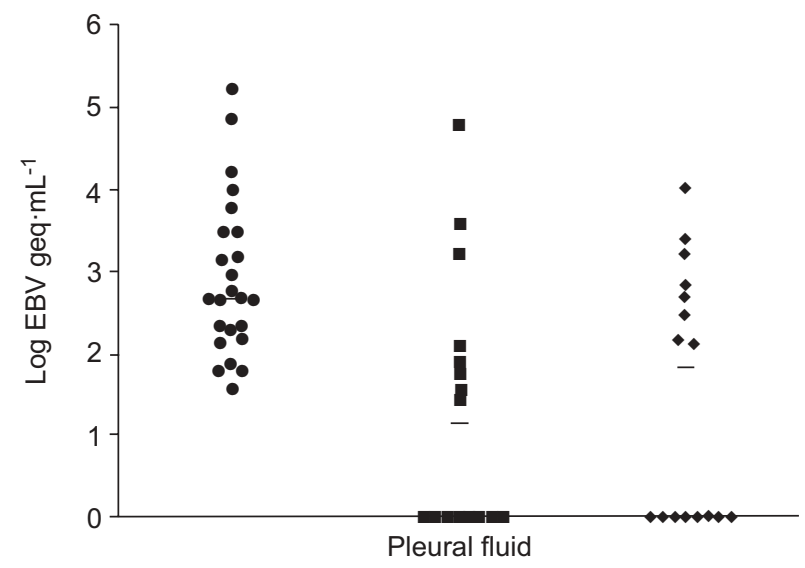

FIGURE 1. Epstein-Barr viral load in pleural fluid. • : total plural fluid; supernatant; $\diamond$ : pellet material. Individual data points indicate the result of the realtime EBV-PCR. Horizontal lines indicate the median load for each catagory. EBV: Epstein-Barr virus; geq: genome equivalent.
TABLE 3 Pleural fluid and serum evaluation

\begin{tabular}{|c|c|c|c|}
\hline & $\begin{array}{c}\text { Positive EBV } \\
\text { PCR on PF }\end{array}$ & $\begin{array}{l}\text { Negative EBV } \\
\text { PCR on PF }\end{array}$ & $p$-value \\
\hline Empyema $(\mathbf{y} / \mathbf{n})^{\#}$ & $1 / 23$ & $3 / 29$ & NS \\
\hline Malignant cells in PF $(y / n)^{\#}$ & $0 / 21$ & $7 / 25$ & 0.034 \\
\hline PF LDH IU.L"-1 & $591 \pm 5269$ & $555 \pm 1649$ & 0.049 \\
\hline Serum LDH IU. $\mathrm{L}^{-1}$ & $427 \pm 842$ & $427 \pm 294$ & NS \\
\hline PF protein $\mathbf{g} \cdot \mathrm{L}^{-1}$ & $40 \pm 92.1$ & $37 \pm 13.3$ & NS \\
\hline PF cell count $\times 10^{9} \cdot \mathrm{L}^{-1}$ & $1.3 \pm 3.7$ & $1.0 \pm 33.4$ & NS \\
\hline Transudate & 2 & 13 & 0.007 \\
\hline Exudate & 20 & 17 & \\
\hline PF diagnosis $(y / n)^{\circ}$ & $4 / 20$ & $22 / 14$ & 0.001 \\
\hline PF location & & & 0.034 \\
\hline Left & 12 & 15 & \\
\hline Right & 9 & 10 & \\
\hline Bilateral & 1 & 11 & \\
\hline
\end{tabular}

Data presented as median \pm SD unless otherwise stated. EBV: Epstein-Barr virus; PF: pleural fluid; y: yes; $n$ : no; $L D H$ : lactate dehydrogenase; $I U \cdot L^{-1}$ :

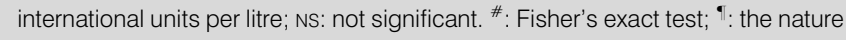
of the pleural effusion was considered clear when an empyema was found, pleuritis carcinomatosa was detected or when the pleural fluid was a transudate based on cardiac disease.

pleural fluid (87\%). Moreover, $92 \%$ of the bilateral effusions were EBV-PCR negative. Both transudates and bilateral effusions were most commonly found in patients with cardiac disease. Furthermore, pleural fluid lactate dehydrogenase was lower in the group of patients with a negative EBV-PCR. This could be explained by the relatively large proportion of transudates in this group. The nature of the pleural effusion was considered clear when a transudate was detected, an empyema was encountered, or malignant cells were found by cytology. In 34 (57\%) out of 60 patients, the diagnosis of pleural effusions remained unexplained; in 20 $(59 \%)$ of these 34 patients, pleural fluids were EBV-PCR positive, whereas in the group in which diagnosis of pleural effusion was clear, EBV-PCR was positive in only four $(15 \%)$ out of 26 cases $(p=0.001)$.

A separate analysis was performed with patients with a pleural fluid EBV-DNA level $>10,000 \mathrm{geq} \cdot \mathrm{mL}^{-1}$ (table 4). Serum EBV PCR was more often positive in patients with a pleural fluid EBV-DNA level $>10,000 \mathrm{geq} \cdot \mathrm{mL}^{-1}(p=0.007)$. All three patients with a pleural fluid EBV-DNA level $>10,000$ geq $\cdot \mathrm{mL}^{-1}$ died during the follow-up period whereas in the group with an EBV-DNA level $<10,000 \mathrm{geq} \cdot \mathrm{mL}^{-1}, 16$ out of 57 died $(p=0.017)$. Two of the three patients in the group with an EBV-DNA level $>10,000 \mathrm{geq} \cdot \mathrm{mL}^{-1}$ died of unexplained bilateral interstitial pneumonia.

\section{DISCUSSION}

In this study a $40 \%$ prevalence of EBV DNA in unselected pleural fluids is documented. This high prevalence increased to $59 \%$ if the analysis was limited to pleural effusions where the nature of the effusion was unclear. These real-time PCR data were confirmed by a different PCR assay targeting another region of the EBV genome [15], (results not shown). 


\begin{tabular}{|c|c|c|c|}
\hline \multirow[t]{2}{*}{ TABLE 4} & $\begin{array}{l}\text { sis of Epstein-Ba } \\
\text { l fluids }\end{array}$ & virus (EBV)-posi & \multirow[b]{2}{*}{ p-value } \\
\hline & $\begin{array}{c}\text { Positive PF } \\
\text { EBV load } \\
<10000 \mathrm{geq} \cdot \mathrm{mL}^{-1}\end{array}$ & $\begin{array}{c}\text { Positive PF } \\
\text { EBV load } \\
>10000 \text { geq } \cdot \mathrm{mL}^{-1}\end{array}$ & \\
\hline Patients $n$ & 21 & 3 & \\
\hline Mortality ${ }^{\#}$ & $6 / 15$ & $3 / 0$ & 0.042 \\
\hline Serum EBV PCR ${ }^{\#}$ & & & 0.010 \\
\hline Positive & 3 & 3 & \\
\hline Negative & 12 & 0 & \\
\hline Malignancy\# & $9 / 12$ & $3 / 0$ & NS \\
\hline Cough & $6 / 9$ & $1 / 1$ & NS \\
\hline $\begin{array}{l}\text { Immunesuppressive } \\
\text { drugs }^{\#}\end{array}$ & $5 / 15$ & $1 / 2$ & NS \\
\hline
\end{tabular}

Data presented as yes/no unless otherwise stated. PF: pleural fluid, geq: genome equivalent; NS: not significant. ${ }^{*}$ : Fisher's exact test.

Most EBV-DNA levels of pleural fluids were relatively low, although three patients showed EBV-DNA levels of $>10,000$ $\mathrm{geq} \cdot \mathrm{mL}^{-1}$. All these patients died within 6 months. Both ethical and technical objections made it impossible to obtain pleural fluid from healthy volunteers. It could be argued that positive EBV-PCR results are caused by the presence of latently infected B-cells present in the pleural fluid. However, this is unlikely since it has been estimated that only 1 in $2 \times 10^{4}-10^{6} \mathrm{~B}$ cells are latently infected $[16,17]$ and copy numbers per cell are low [18]. Each individual PCR was performed on $20 \mu \mathrm{L}$ of pleural fluid with an average cell count of 3,200 cells per $\mu \mathrm{L}$ in the EBV PCR positive group. B-cells account for a maximum of $20 \%$ of the cells in the pleural fluid, therefore, 0.64 EBV-DNA geq/PCR or $32 \mathrm{geq} \cdot \mathrm{mL}^{-1}$ of pleural fluid would be expected, assuming one copy of EBV in each latently infected B-cell, which is $\sim 400$-fold lower that the average load found in the positive samples. However, this does not rule out the possibility that some of the low-positive samples can be explained by the amplification of EBV DNA present in latently infected B-cells. Although this might explain the amount of EBV DNA in some of the low-positive samples, latently infected B-cells are not likely to be the cause of the 400fold higher load that was detected, on average, in positive samples.

EBV could not be detected in pleural fluid using ISH. The cells in which replication occurs could be rare and may produce a relatively large amount of virus per cell. Alternatively, cells located in the pleural wall may be infected with EBV, although at present it is not known whether pleural mesothelial cells are susceptible to EBV infection. An additional sample was obtained from the patient with the highest pleural fluid load. ISH revealed occasional EBV positive lymphocytes, presumably B-lymphocytes, and no expression of EBNA2, or latent membrane protein 1 was seen.

In $93 \%$ of cases, serology was consistent with a previous infection, whereas $7 \%$ were EBV naive. No acute EBV infections were observed. All pleural fluid samples positive in the
EBV PCR were derived from patients with a serological-profile consistent with a previous infection. A total of six out of 44 $(14 \%)$ patients with pleural effusion had a positive EBV-PCR in serum. This increased to $33 \%$ if the analysis was limited to pleural effusion with a positive EBV-PCR. However, in $67 \%$ of patients with a positive EBV-PCR in pleural fluid, serum EBV PCR was negative, suggesting that the presence of EBV in the pleural space is the result of local reactivation of the virus. In addition, the presence of EBV DNA in the supernatant of pleural fluid was demonstrated. To prevent cell lysis, including latently infected B-cells, mild centrifugation was performed. Therefore, positive EBV-PCR results are likely to reflect the presence of cell-free virus rather than EBV DNA only.

Quantitative EBV PCR data are available from patients with primary EBV infections; median EBV-DNA levels in serum have been reported to range from 251 [19] to $3,847 \mathrm{geq} \cdot \mathrm{mL}^{-1}$ [13]. EBV-DNA levels in serum have also been evaluated in post-stem-cell transplant patients. VAN ESSER et al. [3] reported median serum loads of $535 \mathrm{geq} \cdot \mathrm{mL}^{-1}$ in cases of EBV reactivation and $110,000 \mathrm{geq} \cdot \mathrm{mL}^{-1}$ in cases of patients with an EBV lymphoproliferative disease. The current authors (unpublished data) and others have not found EBV DNA in the serum of healthy volunteers with a serotype matching a previous infection $[7,13]$. Analysis of all pleural fluids with viral loads up to $100 \mathrm{geq} \cdot \mathrm{mL}^{-1}$ show that EBV positive samples were more likely to have a positive EBV-PCR in serum $(p<0.001)$, which indicates that even low-positive pleural fluids in the EBV PCR are of relevance regarding systemic occurrence of EBV. The occurrence of EBV in serum might be explained by leakage of EBV from the pleural fluid into the circulation, alternatively these patients could have suffered from a systemic EBV reactivation.

Pleural effusion is a relatively common clinical finding; in a prospective analysis pleural effusion was observed in $62 \%$ of patients admitted to the intensive care unit [20]. Many cases are transudative effusions, which may be caused by changes in haemodynamics. YANG et al. [21] prospectively analysed 320 patients with pleural effusion and could demonstrate a transudate in 96 cases (30\%). In the current study, $\sim 30 \%$ of cases were transudative in nature. Depending on the case mix of patients a varying percentage of exudative effusions will be caused by malignancy or infection. For the remaining majority, differential diagnosis is broad and a definitive diagnosis, despite intensive searching, often remains enigmatic [8].

Pyothorax associated lymphoma (PAL) is a rare EBV associated B-cell lymphoma, within the pleural space [22]. PAL is characterised by longstanding pleural effusion with high lymphocyte counts and is mainly described in patients with tuberculosis who underwent an evoked pneumothorax in an attempt to treat tuberculosis. Long term, in such patients, a malignant pleural lymphoma might develop [23]. Another well described entity in the pleural space is the primary effusion lymphoma, which can affect both HIV-negative and HIVpositive patients and is strongly associated with both human herpes virus-8 and EBV [24-26]. However, no reports exist on the prevalence of EBV in nonlymphoma pleural effusions, although pleural effusion has been described in patients with primary EBV infection [9-11]. 
It could be speculated that Epstein-Barr virus was produced by activated B-cells entrapped in pleural fluid, since T-cell control in pleural fluid might be inadequate. This hypothesis is strengthened by the finding that pleural fluids with a cardiac origin (transudates) with a short duration are mostly negative. Epstein-Barr viral reactivation in the pleural fluid may be a mere bystander phenomenon reflecting decreased cellular immunity or activation of B-cells triggered by an infection with other microorganisms. The findings from this study suggests the existence of Epstein-Barr virus associatedpleuritis and warrants further study on the possible aetiological involvement of Epstein-Barr virus in the pathogenesis of pleural effusions.

\section{ACKNOWLEDGEMENTS}

The authors would like to thank M. Tersmette for critically reviewing the manuscript and $C$. Granger for revising the English grammar and spelling.

\section{REFERENCES}

1 Cohen JI. Epstein-Barr virus infection. N Engl J Med 2000; 343: 481-492.

2 Thorley-Lawson DA, Gross A. Persistence of the EpsteinBarr virus and the origins of associated lymphomas. $N$ Engl J Med 2004; 350: 1328-1337.

3 van Esser JW, van der HB, Meijer E, et al. Epstein-Barr virus (EBV) reactivation is a frequent event after allogeneic stem cell transplantation (SCT) and quantitatively predicts EBV-lymphoproliferative disease following T-cell-depleted SCT. Blood 2001; 98: 972-978.

4 Baldanti F, Grossi P, Furione M, et al. High levels of Epstein-Barr virus DNA in blood of solid-organ transplant recipients and their value in predicting posttransplant lymphoproliferative disorders. J Clin Microbiol 2000; 38 : 613-619.

5 Ling PD, Vilchez RA, Keitel WA, et al. Epstein-Barr virus DNA loads in adult human immunodeficiency virus type 1-infected patients receiving highly active antiretroviral therapy. Clin Infect Dis 2003; 37: 1244-1249.

6 Kimura H, Hoshino Y, Kanegane H, et al. Clinical and virologic characteristics of chronic active Epstein-Barr virus infection. Blood 2001; 98: 280-286.

7 van Kooy B, Thijsen SFT, Meijer E, et al. Sequence analysis of EBV DNA isolated from mouth washings and PBMC's of healthy individuals and blood of EBV-LPD patients. $J$ Clin Virol 2003; 28: 85-92.

8 Collins TR, Sahn SA. Thoracocentesis. Clinical value, complications, technical problems, and patient experience. Chest 1987; 91: 817-822.

9 Offit PA, Fleisher GR, Koven NL, Plotkin SA. Severe Epstein-Barr virus pulmonary involvement. I Adolesc Health Care 1981; 2: 121-125.

10 Alpert G, Fleisher GR. Complications of infection with Epstein-Barr virus during childhood: a study of children admitted to the hospital. Pediatr Infect Dis 1984; 3: 304-307.

11 Chen J, Konstantinopoulos PA, Satyal S, Telonis J, Blair DC. Just another simple case of infectious mononucleosis? Lancet 2003; 361: 1182.
12 Heffner JE, Brown LK, Barbieri CA. Diagnostic value of tests that discriminate between exudative and transudative pleural effusions. Primary Study Investigators. Chest 1997; 111: 970-980.

13 Niesters HG, van Esser J, Fries E, Wolthers KC, Cornelissen J, Osterhaus AD. Development of a real-time quantitative assay for detection of Epstein-Barr virus. J Clin Microbiol 2000; 38: 712-715.

14 Niesters HG. Clinical virology in real time. J Clin Virol 2002; 25: Suppl. 3, 3-12.

15 Berger C, Day P, Meier G, Zingg W, Bossart W, Nadal D. Dynamics of Epstein-Barr virus DNA levels in serum during EBV-associated disease. J Med Virol 2001; 64: 505-512.

16 Decker LL, Klaman LD, Thorley-Lawson DA. Detection of the latent form of Epstein-Barr virus DNA in the peripheral blood of healthy individuals. J Virol 1996; 70: 3286-3289.

17 Wagner HJ, Bein G, Bitsch A, Kirchner H. Detection and quantification of latently infected $B$ lymphocytes in Epstein-Barr virus-seropositive, healthy individuals by polymerase chain reaction. J Clin Microbiol 1992; 30: 2826-2829.

18 Miyashita EM, Yang B, Lam KM, Crawford DH, ThorleyLawson DA. A novel form of Epstein-Barr virus latency in normal B cells in vivo. Cell 1995; 80: 593-601.

19 Kimura H, Nishikawa K, Hoshino Y, Sofue A, Nishiyama Y, Morishima T. Monitoring of cell-free viral DNA in primary Epstein-Barr virus infection. Med Microbiol Immunol (Berl) 2000; 188: 197-202.

20 Mattison LE, Coppage L, Alderman DF, Herlong JO, Sahn SA. Pleural effusions in the medical ICU: prevalence, causes, and clinical implications. Chest 1997; 111: 1018-1023.

21 Yang PC, Luh KT, Chang DB, Wu HD, Yu CJ, Kuo SH. Value of sonography in determining the nature of pleural effusion: analysis of 320 cases. Am J Roentgenol 1992; 159: 29-33.

22 Daibata M, Taguchi T, Nemoto Y, et al. Epstein-Barr virus (EBV)-positive pyothorax-associated lymphoma (PAL): chromosomal integration of EBV in a novel CD2-positive PAL B-cell line. Br J Haematol 2002; 117: 546-557.

23 Nakatsuka S, Yao M, Hoshida Y, Yamamoto S, Iuchi K, Aozasa K. Pyothorax-associated lymphoma: a review of 106 cases. J Clin Oncol 2002; 20: 4255-4260.

24 Hengge UR, Ruzicka T, Tyring SK, et al. Update on Kaposi's sarcoma and other HHV8 associated diseases. Part 2: pathogenesis, Castleman's disease, and pleural effusion lymphoma. Lancet Infect Dis 2002; 2: 344-352.

25 Dourmishev LA, Dourmishev AL, Palmeri D, Schwartz RA, Lukac DM. Molecular genetics of Kaposi's sarcomaassociated herpesvirus (human herpesvirus-8) epidemiology and pathogenesis. Microbiol Mol Biol Rev 2003; 67: 175-212.

26 Jenner RG, Maillard K, Cattini N, et al. Kaposi's sarcomaassociated herpesvirus-infected primary effusion lymphoma has a plasma cell gene expression profile. Proc Natl Acad Sci USA 2003; 100: 10399-10404. 